\title{
Plaučių tuberkuliozės ambulatorinio gydymo problemos ir sprendimai
}

\author{
Stanislava Manukian \\ Romainių tuberkuliozès ligoninè
}

Reikšminiai žodžiai: tuberkuliozė, tiesiogiai stebimo standartizuoto gydymo strategija (DOTS), daugeliui vaistų atspari tuberkuliozė. Santrauka. Tuberkuliozè - visuomenei pavojinga liga, todèl ją būtina kontroliuoti. Efektyviausias TB kontrolès metodas yra PSO rekomenduota tiesiogiai kontroliuojamo standartizuoto gydymo strategija (DOTS). Lietuvoje DOTS pradèta igyvendinti 1998 metais ir dabar pagal šią strategiją dirba visa šalis. Žinant, kad tuberkuliozes išgydymas yra geriausia profilaktika, pagrindinis programos tikslas - nepertraukiamu, kontroliuojamu, standartiniu gydymu išgydyti daugiau kaip 85 proc. sergančiuju atvirajja plaučiu tuberkulioze (TB). Nepertraukiamą gydymą padeda užtikrinti socialinė parama, ligonio ir jo šeimos narių mokymas. Svarbus vaidmuo kontroliuojant ambulatorinį sergančiujų TB gydymą teks bendruomenès ir pirminès sveikatos priežiūros įstaigų bendrosios praktikos slaugytojams.

\section{TUBERKULIOZĖS KONTROLĖS STRATEGIJA IR UŽDAVINIAI}

Tuberkuliozè - viena labiausiai paplitusiu infekcinių ligu pasaulyje: ja kasmet suserga per 8 milijonai gyventojuc ir apie 2 milijonus miršta. 1991 metais PSO asamblèjoje tuberkuliozė buvo pripažinta globalia problema, o tuberkuliozès kontrolè - prioritetine veikla. Asamblëjoje priimtoje rezoliucijoje buvo numatyti uždaviniai, kaip kontroliuoti TB, - sumažinti sergamumą bei mirtingumą visuose pasaulio regionuose. Pagrindiniai rezoliucijos uždaviniai: išsiaiškinti atvirosiomis plaučių tuberkuliozès formomis sergančius asmenis (70 proc.) ir juos išgydyti (85 proc.).

1994 metais PSO patvirtina tiesiogiai kontroliuojamo standartizuoto gydymo strategiją (DOTS) kaip efektyviausią tuberkuliozès kontrolès priemonę. Strategiją sudaro penki pagrindiniai elementai:

1. Vyriausybès parama ir įsipareigojimai igyvendinant TB kontrolès priemones.

2. Ankstyvas atvirąja plaučių tuberkulioze sergančių asmenų išsiaiškinimas. Diagnostikos pagrindas tiesioginè skreplių tepinėlio mikroskopija.

3. Standartizuotas gydymas pirmos eilès preparatais stebint medicinos personalui.

4. Centralizuotas, reguliarus vaistų nuo tuberkuliozès tiekimas, ne mažiau kaip 6 ménesiams sukauptos vaistu atsargas.
5. Naujai išsiaiškintų ligoniu registravimas ir gydymo veiksmingumo kohortinè analizè.

Iki 2004 metų DOTS buvo įdiegta 182 pasaulio šalyse, Europoje - 39, išskyrus Suomiją, Prancūziją, Graikiją, Jungtinę Karalystę, Airiją, Liuksemburgą, Monaką, Ispaniją, Švediją, Šveicariją. Ukrainoje ir Kroatijoje DOTS strategija pradèta igyvendinti 2006 metais. DOTS strategijos uždaviniai sèkmingai igyvendinti tik trečdalyje valstybių: daugiau kaip 85 proc. atvirąja plaučių tuberkulioze sirgusių ligonių išgydyta 53 šalys, iš jų šiose Europos šalyse: Albanijoje, Bosnijoje, Maltoje, Kipre, Norvegijoje, Portugalijoje ir Slovènijoje.

TB epidemiologiniai rodikliai stabilizavosi, bet ženkliai sergamumas nesumažéjo. Didelis sergamumas ir mirtingumas tebèra Afrikoje, Pietryčiu Azijoje, Viduržemio regiono šalyse. Be to, išsikristalizavo naujos problemos:

- Dideja dviem infekcinėmis ligomis - ŽIV/AIDS ir TB - sergančiu asmenų skaičius bei mirtingumas 2008 metais užregistruota $1,4 \mathrm{mln}$. tokių ligonių, 500 tūkst. iš jų mirè.

- Daugèja asmenų, sergančių daugeliui vaistų atsparia TB - 2007 metais užregistruota 500 tūkst. atv., iš jų 40 tūkst. XDR (ypač atsparia daugeliui vaistuc TB). Didesnis kaip 22 proc. pirminis atsparumas daugeliui vaistu nuo TB užregistruotas Indijoje, Kinijoje, $\mathrm{Ru}$ sijoje, Afrikoje ir Bangladeše.

Ivertinusi epidemiologinę situaciją bei naujas problemas, PSO 2006 metais priima ir patvirtina strategiją STOP TB, kurią sudaro šešios dalys:

1. DOTS plètra ir jos tobulinimas - laiku pradètas, tinkamas, nenutrūkstamas ir užbaigtas bet kurios formos TB sergančių pacientų gydymas. Diagnostikos pagrindas - pasèliai bei jautrumo vaistams mėginys.

2. Daugeliui vaistu atsparios TB ir dviejų kartu pasireiškiančių infekciju - ŽIV/AIDS ir TB - gydymas bei kontrolè.

3. Sveikatos priežiūros sistemos stiprinimas (mokymas, naujų diagnostikos technologijų ịdiegimas, informacinių sistemų tobulinimas).

4. Pagalbos tuberkuliozès ligoniams teikimas įtraukiant i i ši darbą visus priežiūros paslaugų tiekèjus.

5. Bendruomeniu informavimas ir jų ittraukimas i paramos TB ligoniams teikimą.

6. Sąlygu moksliniams tyrimams sudarymas bei juc skatinimas.

Šios strategijos iddiegimas padètú igyvendinti globalinị TB planą, PSO numatytą 2007 metais, kuris orientuojasi ì Jungtinių Tautų suformuluotus Tūkstantmečio tikslus.

\section{VEIKSMŲ PLANAS „SUSTABDYTI TUBERKULIOZĘ “}

Tikslai:

- iki 2015 m. sergamumą ir mirtingumą sumažinti 50 proc., palyginti su 1990 metais;

- iki 2050 m. likviduoti TB, kaip problemą, - pasiekti, kad sergamumas 


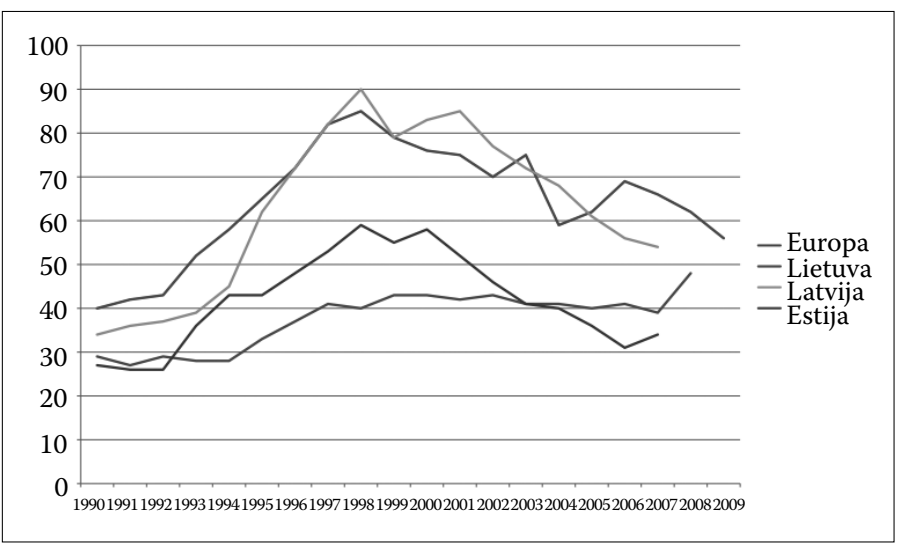

1 pav. SERGAMUMAS TB 100 TÜKST. GYV. 1990-2008 METAIS

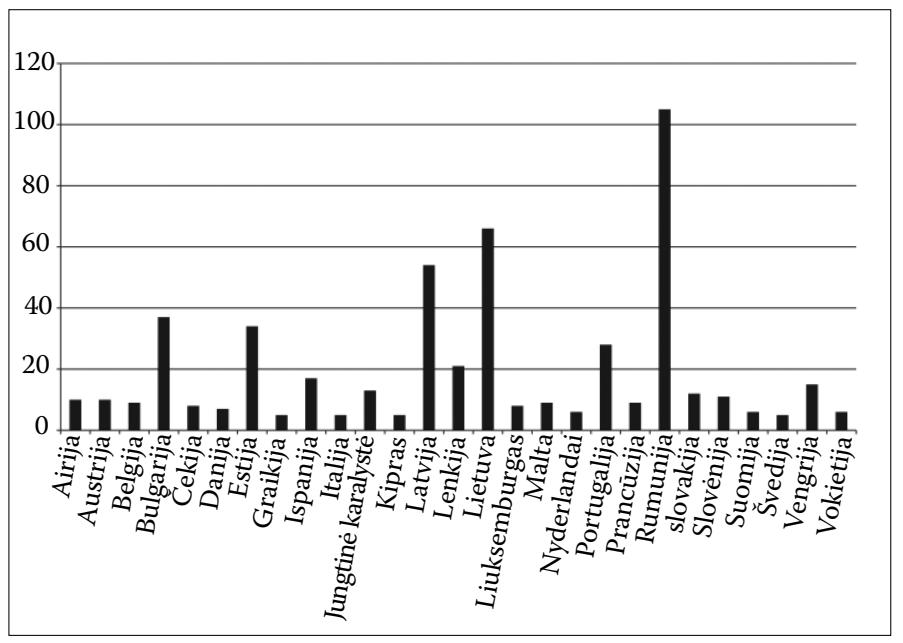

2 pav. SERGAMUMAS TB ES 100 TÜKST. GYV. 2007 METAIS

TB būtuc 1 atv. 1 mln. gyventojų.

Uždaviniai:

- prieinama ir kokybiška TB diagnostika;

- socialinès atskirties ir skurdo mažinimas;

- kokybiška pagalba (nepavèluota diagnostika, gydymas ir profilaktika) sergantiesiems daugeliui vaistų atsparia plaučių TB, taip pat ŽIV/AIDS ir TB kartu;

- naujuc diagnostikos technologijuc, vaistuc ir vakcinuc kūrimas ir spartesnis jų įdiegimas ị praktiką.

\section{DOTS STRATEGIJA LIETUVOJE}

PSO rekomenduojama DOTS strategija Lietuvoje buvo igyvendinama vykdant Valstybinès tuberkuliozès profilaktikos ir kontrolès programas. 1998-2000 metais strategija išbandyta Kaišiadorių, Kelmès, Varènos rajonuose, nuo 2001 metu pradètas antrasis tiesiogiai kontroliuojamo gydymo strategijos igyvendinimo etapas Kaune, Vilniuje, Klaipėdoje, Šiauliuose ir Panevèžyje, o nuo 2007 metu DOTS veikia visoje Lietuvoje. Pradejjus igyvendinti PSO rekomenduojamą strategiją, epidemiologiniai rodikliai per keletą metų stabilizavosi ir pradejjo laipsniškai gerèti (1 pav.). Sergamumas tuberkulioze nuo 81,4 atv. 100 tūkst. gyv. $1998 \mathrm{~m}$. sumažèjo iki 56,6 atv. 2009 metais, bet vis tiek išlieka didžiausias Baltijos šalyse ir vienas didžiausių Europos Sąjungoje po Rumunijos (2 pav.).

Epidemiologinių rodiklių mažèjimą lèmè realizuoti uždaviniai: išsiaiškinta apie 80 proc. atvirąja plaučių tuberkulioze sergančių asmenų ir pavyko išgydyti 82,3 proc. 2008 metais. Igyvendinus DOTS, Lietuvoje sumažejo nutraukto gydymo atvejų nuo 13,4 proc. 1998 m. iki 8,1 proc. $2008 \mathrm{~m}$.

\section{STRATEGIJOS UŽDUOČIŲ İGYVENDINIMAS KAUNO MIESTE IR RAJONE}

Teigiami epidemiologiniai pokyčiai vyksta ir Kauno mieste bei rajone: sergamumas nuo 70,7 atv. 100 tūkst. gyv. 2000 m. sumažèjo iki 54,7 2009 metais, mirtingumas taip pat mažèja: 2001 metais mirè 47 pacientai (12,3 atv. 100 tūkst.gyv.), 2009 m. - 27 (7,6 atv.). Nerimą kelia gan didelis vaiku sergamumas, daugiau nei dvigubai viršijantis Lietuvos rodiklius: šalyje - 15,45 atv. 100 tūkst. gyv., o Kaune - 42,52 atv. Bakteriologiškai nuo 2004 metu TB diagnozė patvirtinama $84-86$ proc. Dažniausiai serga darbingo amžiaus vyrai (35-54 metų), apie 74 proc. naujai išsiaiškintų ligoniu yra bedarbiai arba turintieji nenuolatines pajamas, apie 45 proc. piktnaudžiauja alkoholiu ir dažnai neturi motyvacijos pasveikti.

Nepaisant gan sudètingos ligonių socialinès struktūros, teikiant socialinę paramą ambulatoriškai besigydantiems pacientams, pavyko pasiekti gerų rezultatų. Nutraukto gydymo atvejų nuo 17 proc. $2000 \mathrm{~m}$. sumažejo iki 4,6 proc. 2007 m. (3 pav.). 2003-2008 metais gydymo nebaigè 54 naujai atvirąja plaučiu TB sirgę pacientai. Iš jų 39 (72 proc.) gydėsi apie 3-4 mèn., nustojo skirti Mycobacterium tuberculiosis ir iki šiol bakteriologiškai yra neigiami, 7 pacientai mirè, 3 gydosi iš naujo ir tik 5 ligoniai liko epidemiologiniu požiūriu pavojingi aplinkiniams. Šiuos pacientus sudètinga kontroliuoti, nes neturi nuolatinès gyvenamosios vietos ir nèra prisirašę prie šeimos gydytojo.

Tuberkuliozès kontrolę sunkina daugeliui vaistų atspari tuberkuliozè. Pastarųju 10 metų laikotarpiu bendras jos atvejų skaičius šalyje padidejo nuo 196 asmenų 2000 m. iki 321 - 2009 m., pirminis atsparumas apie 9,8 proc. Kaune kasmet nustatoma apie 10-12 naujų daugeliui vaistų atsparios TB atvejų (4 pav.), čia pirminis atsparumas yra apie 10 proc., o pakartotinai gydomu asmenu grupejje svyruoja nuo 35 iki 56 proc. Daug blogesni ir gydymo rezultatai: pasveiksta apie 50 proc. ligonių, sergančių naujai nustatyta daugeliui vaistų atsparia TB (5 pav.). Gydymą nutraukia apie 17 proc. naujų TB ligonių ir 45 proc. patyrusiųju atkryti, todèl epidemiologiniu požiūriu visuomenèje išlieka pavojingai didelis daugeliui vaistų atsparios TB rezervuaras.

\section{AMBULATORINIO KONTROLIUOJAMO GYDYMO PROBLEMOS IR GALIMI SPRENDIMAI}

Norint pasiekti gerų gydymo rezultatų, būtina kontroliuoti gydymą visais etapais - tiek stacionaro, tiek ambulatorijos sąlygomis. Iki šiol ambulatorinį kontroliuojamą gydymą vykdo II lygmens specialistai (ftiziatras ar pulmonologas) su savo komanda (bendrosios praktikos slaugytoju ir socialiniu darbuotoju):

- Vaistú ligoniams duodama kartą per savaitę bei $2 \mathrm{k} . / \mathrm{sav}$. kompensuojamos transporto išlaidos (nuvykti iki gydytojo ir parvykti);

- Pacientui nutraukus gydymą, pranešama tiesiogiai šeimos gydytojui, prie kurio yra prisirašęs.

- Pacientų, neturinčiu nuolatinès gyvenamosios vietos, ieškoma informuojant seniūnijas. 
- Savivaldybès gydytojas yra informuojamas (GKK sprendimas) apie asmenims, kuriems būtinas priverstinis gydymas nuo TB.

Norint užtikrinti kokybišką kontroliuojamą gydymą būtina plètoti ligonių ir šeimos narių mokymus, nepertraukiamai ir nemokamai aprūpinti vaistais nuo tuberkuliozès, kontroliuoti jų išgèrimą artimiausiose pagal gyvenamąją vietą gydymo ìstaigose, užtikrinti nuolatinę socialinę paramą tvarkingai besigydantiems ligoniams. Dabartiniu metu socialinė parama, vaistų priemokos kompensavimas priklauso nuo programu finansavimo, kuris yra labai netolygus ir nereguliarus. Nustatomas nedarbingumo lygis gydantis tuberkuliozę (neiggalumo grupè) dažnam ligoniui nèra paskata gydytis, o kartais netgi atvirkščiai - tikimasi, kad, nutraukus gydymą ir vėl laikinai atsigulus ị ligoninę, grupe bus pratęsta.

Užtikrinti kokybišką kontroliuojamą gydymą padètų:

- Centralizuotas visų vaistų nuo tuberkuliozès pirkimas.

- Kontroliuojamas vaistų išgèrimas artimiausioje gydymo istaigoje:

- II lygmens specialistas - paciento stebėsena visą gydymosi laikotarpi (subjektyvios ir objektyvios būklès stebèjimas, tyrimų atlikimas, gydymo rezultatu vertinimas);

- tiesiogiai kontroliuojamas gydymas pirminès sveikatos priežiūros įstaigoje, prie kurios pacientas yra prisirašęs ar kuri yra arčiausiai jo gyvenamosios vietos, - kontroliuoja bendrosios praktikos ar bendruomenès slaugytojas (ne šeimos gydytojas);

- kontingentas - po intensyvaus gydymo fazès, kai neskiria Mycobacterium tuberculiosis; daugeliui vaistu atsparia TB sergantys pacientai po 6 mèn. gydymo, kai 3 ménesius paeiliui pasèliuose neišauga Mycobacterium tuberculiosis.

- Socialinè parama - valstybès patvirtintos socialinès išmokos pacientams, kurie nepažeidžia gydymo režimo. Išmokos mokamos kas mènesî, pateikus GKK pažymą Socialinès rūpybos skyriui.

Sèkmingas DOTS strategijos igyvendinimas ir plètra priklauso nuo gero specialistų ir pirminès sveikatos priežiūros darbuotojų tarpusavio ryšio ir bendradarbiavimo, taip pat nuo Vyriausybès bei savivaldybių paramos kontroliuojant šią visuomenei pavojingą infekciją.

\section{OUTPATIENT TB TREATMENT PROBLEMS AND SOLUTIONS}

\section{STANISLAVA MANUKIAN \\ ROMAINIU TUBERCULOSIS HOSPITAL}

Key words: tuberculosis, DOTS, drug-resistant tuberculosis.

Summary. TB is a public-threatening illness, it is necessary to control the infection. The most effective TB control is the way the WHO recommended DOTS strategy.This strategy is the basis for national programs.DOTS was launched in Lithuania in 1998 and after ten years of this strategy is working across the country. Knowing that the cure of TB patients are the best prevention, because the main objective of the program, continuous monitoring, a standard treatment curing over 85 percent of patients with open pulmonary tuberculosis. Social support, patient and family teaching helps ensure uninterrupted treatment. Important role in controlling out-patient treatment of tuberculosis patients will play community nurses and primary health care nurses and local authorities.

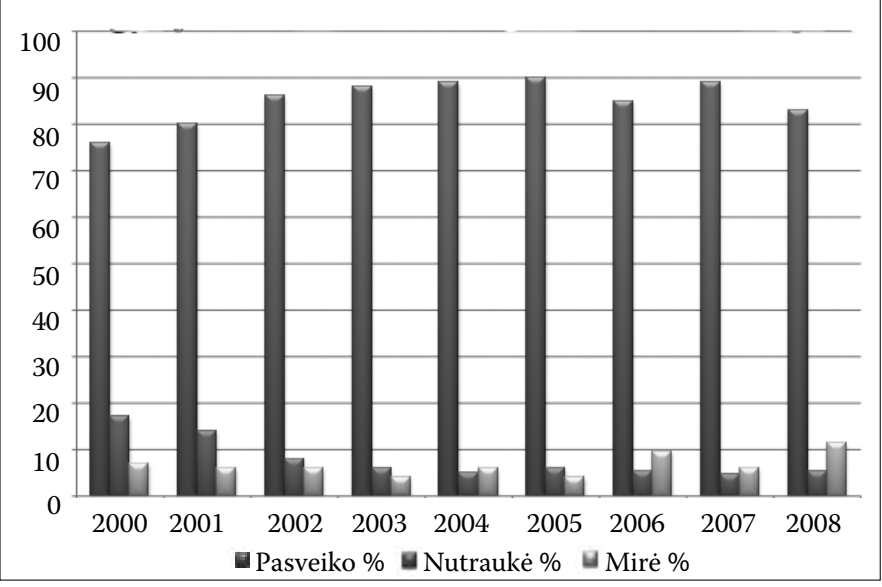

3 pav. NAUJAI NUSTATYTOS ATVIROSIOS PLAUČIŲ TB GYDYMO REZULTATAI* KAUNO MIESTE IR RAJONE

* Neętraukti daugeliui vaistų atsparios TB atvejai

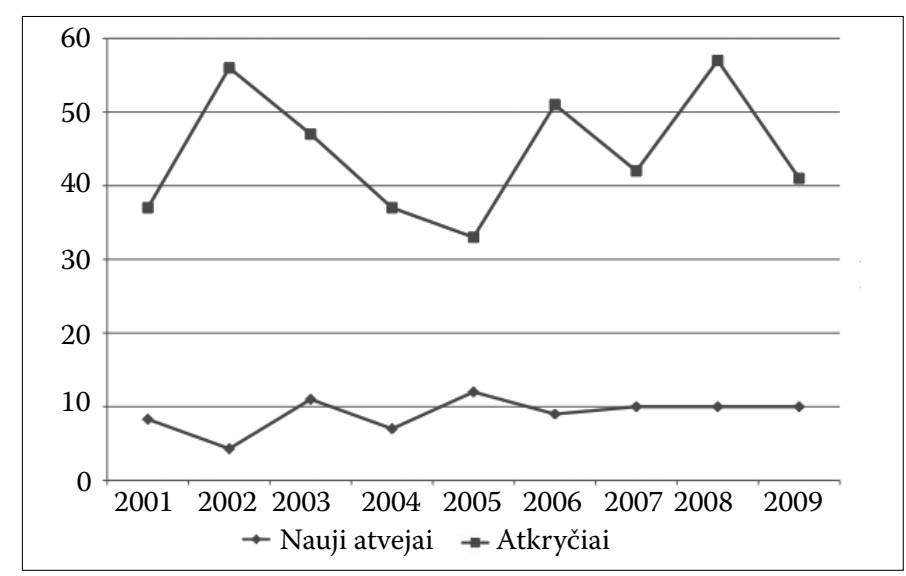

4 pav. DAUGELIUI VAISTŲ ATSPARIOS PLAUČIU TB PAPLITIMAS KAUNO MIESTE IR RAJONE

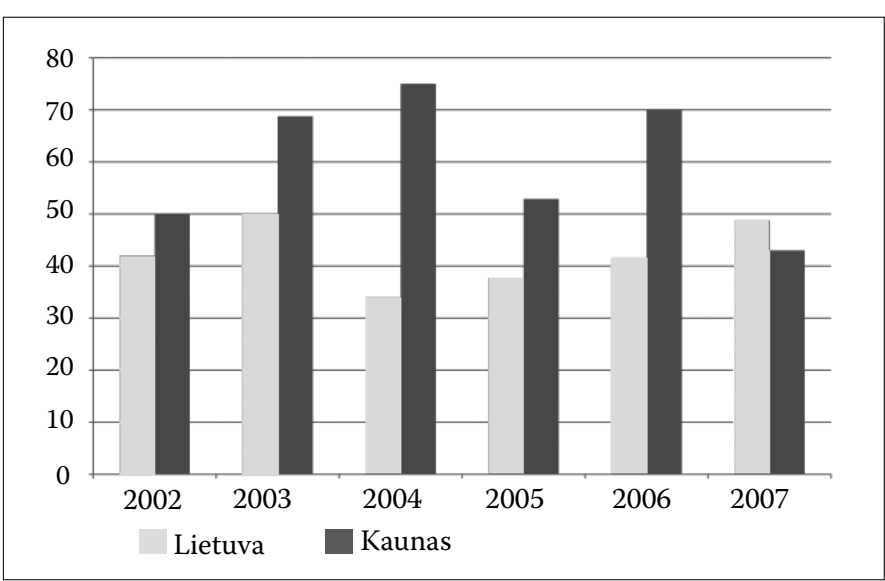

5 pav. NAUJAI NUSTATYTOS DAUGELIUI VAISTŲ ATSPARIOS PLAUČIŲ TB GYDYMO REZULTATAI

\section{LITERATŪRA}

1. World Health Organisation. Stop TB Partnership. The Stop TB Strategy. 2006. 368.

2. World Health Organisation. Global tuberculosis control: surveillance, planning, financing. WHO Report. Geneva; 2007.

3. World Health Organisation. Global tuberculosis control: surveillance, planning, financing. WHO Report. Geneva. 2006.

4. World Health Organisation. Practical Approach to Lung Health (PAL). 2010 prieiga internete www.who.int/tb/

5. Plaučiu tuberkuliozès diagnostikos ir gydymo metodinès rekomendacijos.Vilnius. 2009 